\title{
HANDBOOK OF THE
}

BIRD PF THE WORLD

\section{ORNITHOLOGICAL NOTES}

\section{Notes on the vocalizations of Vivid Niltava (Niltava vivida)}

Peter Boesman

In the following we briefly analyze and compare voice of the two races of Vivid Niltava (Niltava vivida). We also try to quantify the extent of any vocal differences using the criteria proposed by Tobias et al. (2010), as a support for taxonomic review. We have made use of sound recordings available on-line from Xeno Canto (XC), Macaulay Library (ML) and Avian Vocalizations Center (AVoCet).

Song of nominate (Taiwan) is a short strophe of some 5-6 sweet whistles. Song starts typically with one (or 2) descending whistles followed by several pure whistles which form a rhythmic phrase.

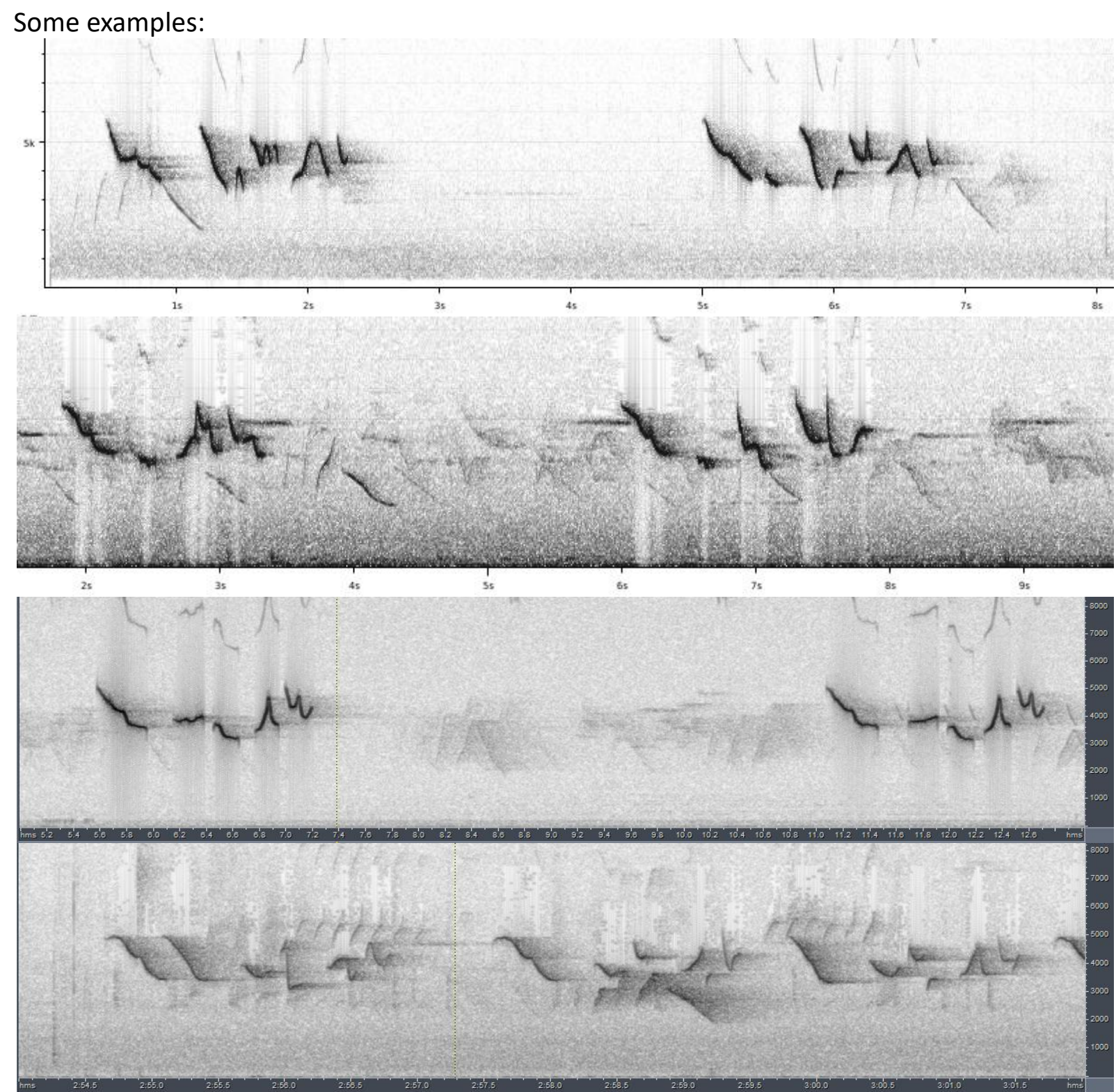



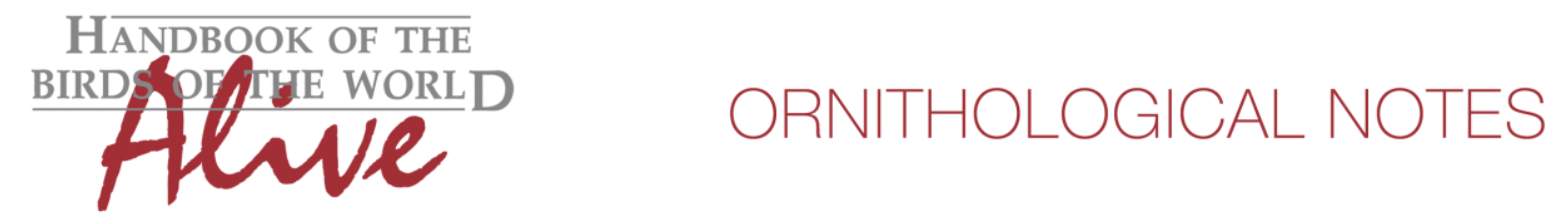

Despite its much larger range, we have only found a single recording of oatesi: (AV\#4027 of Paul Holt from Eastern Tibet)

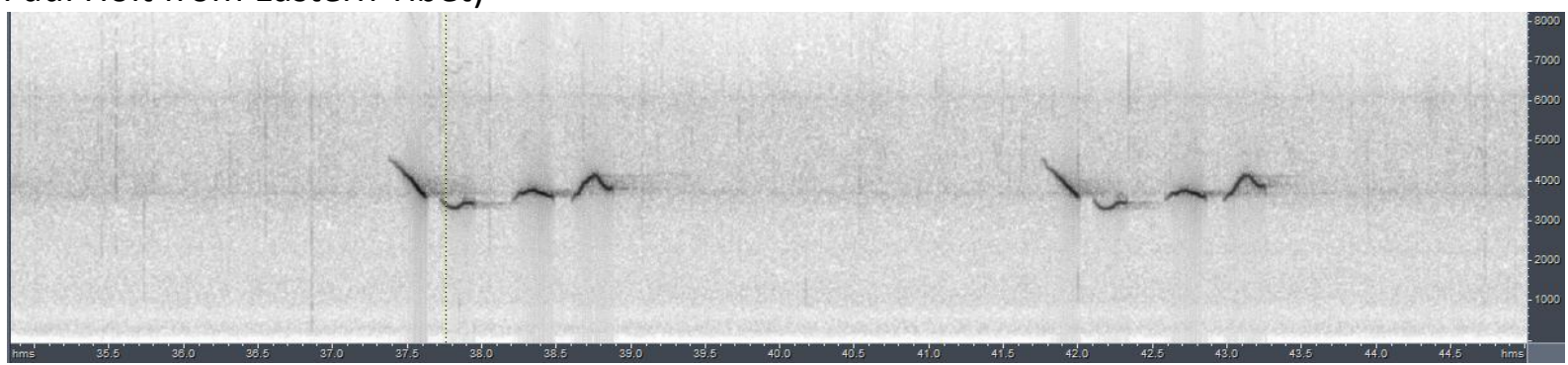

There is also a description and sonogram (of a different recording) in The Ripley guide (Rasmussen \& Anderton 2012).

From the data provided and own measurements on available recordings:

\begin{tabular}{llll} 
The Ripley guide & & \multicolumn{2}{l}{ Own measurements of available recordings } \\
oatesi & nominate & oatesi & nominate \\
$2.6-4.1 \mathrm{kHz}$ & $3.3-5.6 \mathrm{kHz}$ & $3.2-4.5 \mathrm{kHz}$ & $2.9-5.7 \mathrm{kHz}$ \\
$0.1-0.3 \mathrm{~s}$ & $0.1-0.2 \mathrm{~s}$ & $0.2-0.25 \mathrm{~s}$ & $0.1-0.45 \mathrm{~s}$ \\
$2-3 \mathrm{n} / \mathrm{s}$ & $3-4 \mathrm{n} / \mathrm{s}$ & $2.5 \mathrm{n} / \mathrm{s}$ & $2-5 \mathrm{n} / \mathrm{s}$ \\
$1.5-5 \mathrm{~s}$ & $1.5-2 \mathrm{~s}$ & $1.54 \mathrm{~s}$ & $1.6-2 \mathrm{~s}$
\end{tabular}

It would thus seem that the single available recording of oatesi is not really representative. However, the data in The Ripley guide seem to have also been taken from just two recordings from one single region (Sichuan). This suggests that variability of oatesi over its entire range is somewhat larger.

If we merge the data of The Ripley guide and own measurements for both oatesi and nominate, we get:

$\begin{array}{lll} & \text { oatesi } & \text { nominate } \\ \text { min freq. } & 2.6-3.2 \mathrm{kHz} & 2.9-3.3 \mathrm{kHz} \\ \text { max freq. } & 4.1-4.5 \mathrm{kHz} & 5.2-5.7 \mathrm{kHz} \\ \text { note length } & 0.1-0.3 \mathrm{~s} & 0.1-0.45 \mathrm{~s} \\ \text { pace } & 2-3 \mathrm{n} / \mathrm{s} & 2-5 \mathrm{n} / \mathrm{s} \\ \text { strophe length } & 1.5-5 \mathrm{~s} & 1.5-2 \mathrm{~s} \\ \text { freq. range } & 1.3-1.5 \mathrm{kHz} & 2.3-2.8 \mathrm{kHz}\end{array}$

All in all, differences thus seem to be rather subtle, and more recordings of oatesi are needed to have a better understanding of the extent of variation.

It would seem that nominate has a slightly higher pitched song, reaching higher frequencies (score 2 ) and having a larger overall freq. range (score 2-3). 
This note was finalized on 22nd June 2016, using sound recordings available on-line at that moment. We would like to thank in particular the sound recordists who placed their recordings for this species on XC, ML and AVoCet: Paul Holt, Frank Lambert, Pamela Rasmussen, Sheldon Severinghaus, Hsu Wayne and Yong Ding Li.

\section{References}

Rasmussen, P.C. \& Anderton, J.C. (2012). Birds of South Asia. The Ripley Guide. Second edition. Lynx edicions. Barcelona.

Tobias, J.A., Seddon, N., Spottiswoode, C.N., Pilgrim, J.D., Fishpool, L.D.C. \& Collar, N.J. (2010). Quantitative criteria for species delimitation. Ibis 152(4): 724-746.

\section{Recommended citation}

Boesman, P. (2016). Notes on the vocalizations of Vivid Niltava (Niltava vivida). HBW Alive Ornithological Note 319. In: Handbook of the Birds of the World Alive. Lynx Edicions, Barcelona. (retrieved from http://www.hbw.com/node/1252364 on 20 October 2016). 